\title{
Population estimation of freshwater crocodiles (Crocodylus novaeguineae) and tree vegetation diversity at wildlife reserve of Mamberamo Foja, Papua, Indonesia
}

\author{
SUHARNO ${ }^{1, \vartheta}$, AKHMAD KADIR ${ }^{2}$, EDWARD SEMBIRING ${ }^{3}$, ASKHARI DG. MASIKI ${ }^{3}$, TAUFIK MUBARAK ${ }^{3}$, \\ NAFLI LESSIL ${ }^{4}$, LUSIANA D. RATNAWATI ${ }^{3}$, DANIAL IDRIS ${ }^{3}$, JOHAN G. IMBENAI ${ }^{3}$ \\ ${ }^{1}$ Department of Biology, Faculty of Mathematics and Natural Sciences. Universitas Cenderawasih. J1. Kamp. Wolker, Waena, Jayapura 99224, Papua, \\ Indonesia. "email: harn774@gmail.com \\ ${ }^{2}$ Department of Anthropology, Faculty of Social and Political Sciences, Universitas Cenderawasih. Jl. Kamp. Wolker, Waena, Jayapura 99224, Papua, \\ Indonesia \\ ${ }^{3}$ Papua Natural Resources Conservation Center. J1. Raya Abepura, Kotaraja, Jayapura 99351, Papua, Indonesia \\ ${ }^{4}$ Intsia Foundation in Tanah Papua. Jl. Wahno, Abepura, Jayapura 99224, Papua, Indonesia
}

Manuscript received: 25 May 2021. Revision accepted: 26 June 2021.

\begin{abstract}
Suharno, Kadir A, Sembiring E, Masiki AD, Mubarak T, Lessil N, Ratnawati LD, Idris D, Imbenai JG. 2021. Population estimation of freshwater crocodiles (Crocodylus novaeguineae) and tree vegetation diversity at wildlife reserve of Mamberamo Foja, Papua, Indonesia. Biodiversitas 22: 2928-2936. The structure and composition of vegetation in the conservation area have a major influence on the existence of other flora and fauna, including freshwater crocodiles (C. novaeguineae). Wildlife Reserve of Mamberamo Foja (WRMF) is a conservation area in Papua that aims to protect the habitat and existence of freshwater crocodiles. The purpose of this study was to estimate the number of freshwater crocodile populations and tree species diversity in the WRMF, Papua. The method used was a field survey. The crocodile survey was carried out using the spotlight night count method. Tree species diversity was assessed using the line-transect plot method in 6 different locations representing the Upper, Central, and Lower Mamberamo. The results of the investigation showed that the freshwater crocodile population in the WRMF was around 0.3-19.7 individuals per kilometer. The population of this freshwater crocodile was very high, with an average of 4.5 individuals per 1-kilometer distance. The highest population numbers were found in the upstream Mamberamo River area 6.22 ind./km, followed by the central Mamberamo (2.21 ind./km) and downstream Mamberamo area (2.05 ind./km). Crocodiles were found in the Mamberamo River and other river systems, such as swamps and lakes. The tree vegetation in this area is still relatively good, and there are 112 species, dominated by the Moraceae, Burseraceae, Myrtaceae, Rubiaceae, Lauraceae, Dipterocarpaceae, and Euphorbiaceae families. The results of this study are important as a basis for determining the conservation policy for freshwater crocodiles that have limited distribution.
\end{abstract}

Keywords: Conservation, habitat, tree diversity, Mamberamo river, Papua

\section{INTRODUCTION}

Tropical rain forests have ecosystems with complex dynamics that contain a variety of habitats that support various species. As a country located in tropical region, Indonesia is rich in biological resources (Kartikasari et al. 2012). Indonesia is located on the equator has a large forest area to be one of the centers of biodiversity in the world (Kartikasari et al. 2012; Kadir et al. 2020), including Crocodylus novaeguineae Schmidt, 1928 in Papua (Cox 2010; Man et al. 2011; Murray et al. 2019).

The crocodile ( $C$. novaeguineae), based on Wildlife Conservation Law, Number 5, 1990 and Government Regulation No. 7 Year 1999, C. novaeguineae is a protected species (Kurniati et al. 2017). Wild harvest of $C$. novaeguineae is only allowed in specific areas of Papua and West Papua Provinces (Indonesia), and Papua New Guinea (PNG) (Montague 1984; Hall and Johnson 1987; Britton 2012; Murray et al. 2019). Based on the status of freshwater crocodiles in CITES Appendix II in 1990 and decree of the Minister of Agriculture, revealed that the utilization of crocodiles for commercial purposes is widely done, so that the status of its population in nature can be endangered (Kurniati et al. 2017). According to the International Union for Conservation of Nature (IUCN) Red List of Threatened Species 2019 status $C$. novaeguineae including lower risk/least concern that needs attention (Solmu and Manolis 2019).

Wildlife sanctuary is a nature reserve area that has the peculiarity/uniqueness of the type of wildlife and/or diversity of wildlife that for its survival requires efforts to protect and foster the population and habitat. Wildlife Reserve of Mamberamo Foja (WRMF) with an area of about 1.7 million hectares aims to protect and preserve the survival of animals (C. novaeguineae) so as not to become extinct and maintain their habitat. The habitat of freshwater crocodiles in this area includes lowland swamps dominated by freshwater systems including Mamberamo rivers, small rivers, lakes, ponds, and swamps. The WRMF area crosses the Mamberamo watershed. WRMF is administratively located in 12 districts in Papua, namely: Jayapura, Mamberamo Raya, Keerom, Sarmi, Central Mamberamo, Yalimo, Puncak, Tolikara, Yahukimo, Pegunungan Bintang, Intan Jaya, and Puncak Jaya. In the management 
system, intensive coordination between districts is required, and important flora and fauna data is needed in this region.

On the other hand, population growth and land conversion are the main problems of forest area decline (Kadir et al. 2020). In such conditions, the susceptibility to forest destruction is quite high, which can result in the loss of various types of flora, fauna, and including the habitat where they live. To avoid the extinction of flora and fauna, one of the efforts is to conserve forest areas. Forest areas need to be protected and developed as an effort to maintain biodiversity (Indrawan et al. 2007; Hermawan et al. 2014).

The condition of plant diversity in conservation areas is very important because interactions of plants in forests affect the existence of living things of their inhabitants (Hunter 1996; Cape et al. 2012; IFACS 2014). Data on the diversity of tree species and their changes will be very important for monitoring conservation areas (Papua Regional Government 2012). The purpose of this study is to investigate the population of $C$. novaeguineae, habitat, and diversity of tree vegetation in the WRMF area, Papua. This data will be useful for planning, controlling, and monitoring conservation areas, especially the conformity of WRMF functions in Papua.

\section{MATERIALS AND METHODS}

\section{Research area and period}

This research was conducted in Wildlife Reserve of Mamberamo Foja (WRMF) conservation area, Papua, Indonesia. Field observations were conducted from November 2018 to January 2019. Sampling locations were conducted in four (6) different locations, namely Pagai Village in Airu Sub-district (Jayapura District/kabupaten), Dabra 2 Villages and Dorman River (Upper Mambearmo Sub-district) Korwate Pond (Rufaer Sub-district), and Kwerba Village (Central Mamberamo Sub-district), and Suaseso Village (Lower Mamberamo Sub-district) (Figure 1; Table 1). Plant species identification and data analysis were conducted in January-March 2019. Crocodile surveys were conducted spread within conservation areas (Table 2). Crocodile population data were obtained from the monitoring of Papua Natural Resources Conservation Agency (Balai Besar Konservasi Sumber Daya Alam, BBKSDA) Papua, which is conducted periodically every year with a location that is not always the same, but represents all regions.
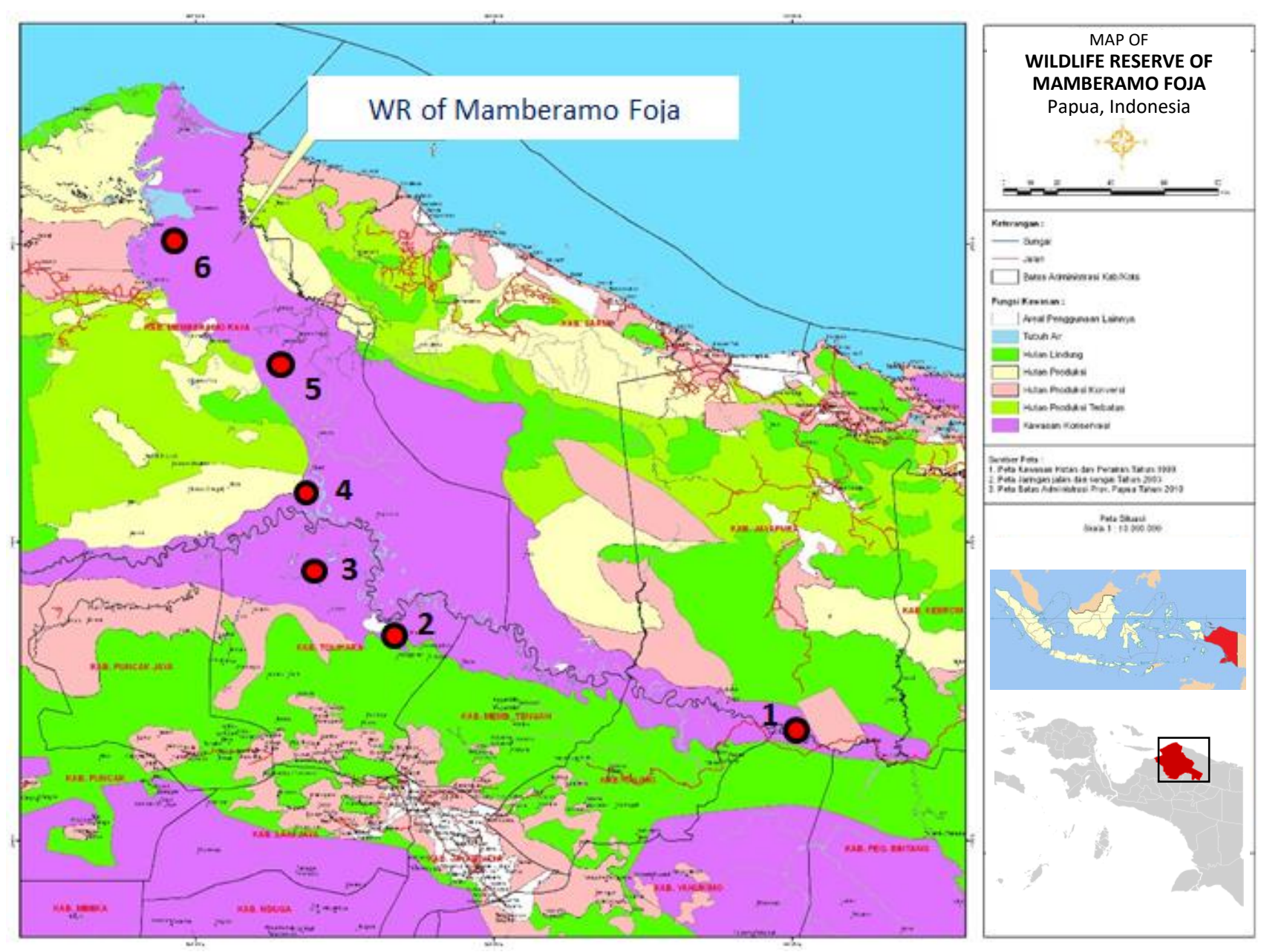

Figure 1. Study location of Crocodylus novaeguineae in the Wildlife Reserve of Mamberamo Foja (WRMF), Papua, Indonesia. 1. Pagai, 2. Dabra, 3. Dorman Times, 4. Korwate Pond, 5. Kwerba, 6. Suaseso 


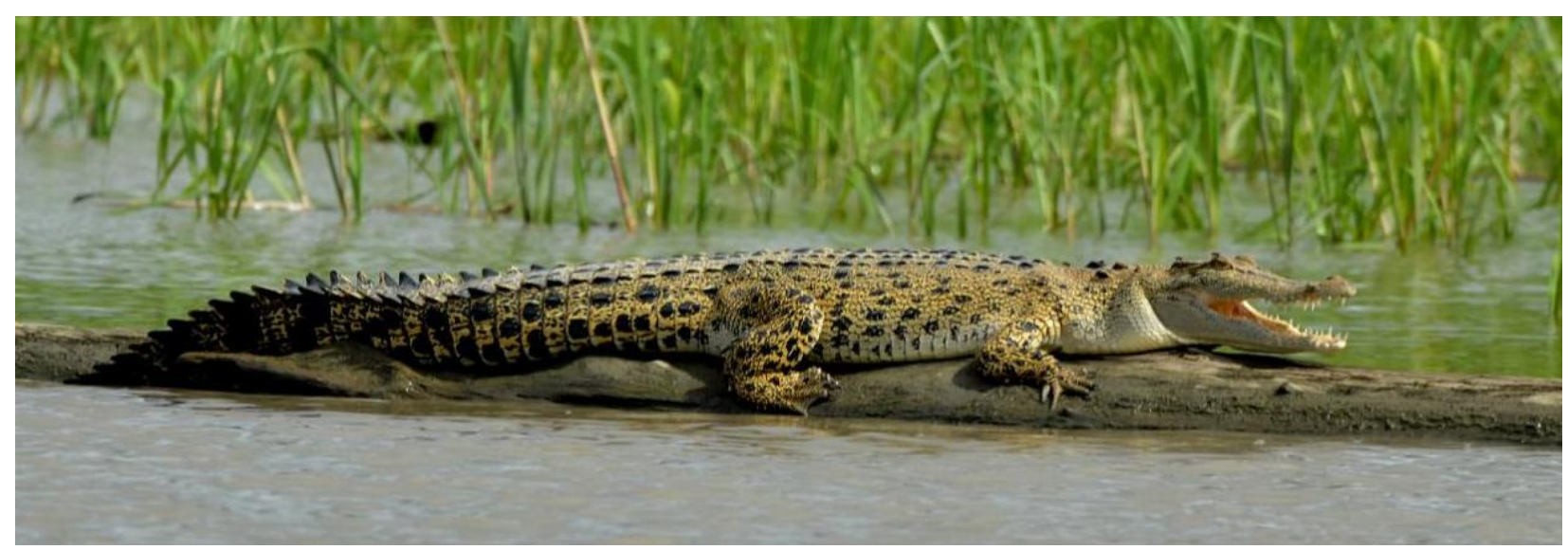

Figure 2. Morphology of Crocodylus novaeguineae in WRMF, Papua, Indonesia (Photograph: P.N. Septhiawan, 2018)

Table 1. Observation sites in six (6) villages of WRMF area, Papua, Indonesia

\begin{tabular}{|c|c|c|c|c|}
\hline Sub-district & Location (Village) & Coordinate & Alt. (m asl.) & Temp. $\left({ }^{\circ} \mathrm{C}\right)$ \\
\hline Airu & Pagai & S: $04^{\circ} 02^{\prime} 54,4^{\prime \prime} ;$ E: $138^{\circ} 56^{\prime} 45,8^{\prime \prime}$ & $60-100$ & $26-28$ \\
\hline Upper Mamberamo & Dabra 2 & S: $03^{\circ} 16^{\prime} 32,2^{\prime \prime} ;$ E: $138^{\circ} 37^{\prime} 11,2^{\prime \prime}$ & $77-207$ & $26-29$ \\
\hline Upper Mamberamo & Dorman Times & S: $03^{\circ} 15^{\prime} 17,0^{\prime \prime} ;$ E: $138^{\circ} 35^{\prime} 11,2^{\prime \prime}$ & $52-93$ & $26-30$ \\
\hline Rufaer & Korwate Pond (Korwate) & S: $02^{\circ} 59^{\prime} 47,4 "$; E: $138^{\circ} 21^{\prime} 49,9^{\prime \prime}$ & $51-55$ & $26.5-30$ \\
\hline Central Mamberamo & Kwerba & S: $02^{\circ} 38^{\prime} 27,3^{\prime \prime}$; E: $138^{\circ} 24^{\prime} 93,3^{\prime \prime}$ & $89-100$ & $26-30$ \\
\hline Downstream Mamberamo & Suaseso & S: $01^{\circ} 97^{\prime} 47,1^{\prime \prime} ;$ E: $138^{\circ} 95^{\prime} 46,0^{\prime \prime}$ & $50-100$ & $27-29$ \\
\hline
\end{tabular}

\section{Survey method of Crocodylus novaeguineae}

The crocodile population survey was conducted with spotlight night count method (Mauger et al. 2012). Observations were made at night using a flashlight. Transportation tools used for surveying are speedboats, longboats, and boats. Some locations with difficult access conditions were reached on foot. Global Positioning System (GPS) is used to determine distance during the survey. Crocodiles found were recorded according to the age group, namely hatchlings (infants), juveniles (juvenile), and adults (Figure 2). The group of hatchling category crocodiles differs between the southern and northern populations of Papua, according to Cox (2010) the length of hatchlings ranges from 21-27 cm for the northern part of Papua. The habitat condition of freshwater crocodiles is qualitatively described.

\section{Diversity of tree vegetation species}

The research sampling site is part of the WRMF area representing all conservation areas. Six (6) designated locations represent areas spread from the Upper Mamberamo watershed to downstream in the Mamberamo river estuary area (Table 1). To see the diversity and structure of treelevel vegetation, it is done by transect method. Transect is done in every area of the village forest. Plot observation as much as 20 pieces each measuring $10 \times 10 \mathrm{~m}$ for each location, so the total sampling vegetation about $2,000 \mathrm{~m}^{2}$. The distance between the plots is about $20 \mathrm{~m}$., which passes intermittently on the left and right of the transect line. The total plot carried out in 6 locations is 120 plots.

\section{Identification of tree vegetation}

Identification of tree vegetation species was conducted at the Biology Laboratory, Faculty of Mathematics and Natural Sciences, Cenderawasih University, Jayapura. Unidentified samples were sent to Herbarium Manokwariense for further identification.

\section{Data analysis}

The data were qualitatively analyzed. Data is organized in a table by taxonomic classes based on morphological recognition findings.

\section{RESULTS AND DISCUSSION}

\section{Population of Crocodylus novaeguineae}

Observations showed that freshwater crocodile populations in the WRMF area ranged from 0.3-19.7 individuals $/ \mathrm{km}$ (data after 2001). This means that each kilometer-long cruising survey is found between 0.3-19.7 individuals (Table 2; Figure 3). The population of freshwater crocodiles was very high, with an average of 4.5 individuals per 1-kilometer distance passed in the survey. Mamberamo Foja area in the upper part (Dabra, Mamberamo to Pagai, Jayapura), is known to still have a higher population than the other two regions in central and downstream Mamberamo. In the central WRMF region, the population is only 2.21 individuals $/ \mathrm{km}$ and the downstream is only 2.05 individuals $/ \mathrm{km}$. According to observations 
made by Mauger et al. (2012) of $C$. acutus in the Pacific Costa Rica region between 2007 and 2009, the average was only about 1.2-4.3 ind./km., while in the Osa Conservation Area (ACOSA) between 2008 and 2009, about 2.9-14.1 ind. $/ \mathrm{km}$.

The hatchling group was found to have a higher population than the juvenile and adult groups, based on the age groups of crocodiles found (Figure 3). The data revealed that the average population of adult crocodiles is smaller than that of hatching and juvenile crocodiles. According to group interviews, crocodile hunting by the community has continued until the beginning of 2019. The study's findings revealed that the WRMF habitat in the upper Mamberamo River (southern region) is in good shape. The habitat type of this area is a lowland swamp area dominated by sago plants (Metroxylon sago). The population in this area is not dense compared to the downstream which is the capital area of Central Mamberamo District. This condition supports the growth of crocodiles so that the crocodile population in WRMF is still high. The results of the 2018/2019 Evaluation of Functional Conformity Evaluation (EKF) team showed that this conservation area was inhabited by local residents who had existed before the establishment of Mamberamo area as WRMF.

The survey of crocodile population was conducted by means of transportation in the form of traditional boats, speed, longboats, and without means of transportation (walking). This method, of course, obtained diverse data. The utilization of boat transportation and without tools (walking) showed higher observations reaching 11.03 ind./km and 7.34 ind./km. The utilization of speedboats and longboats only obtained about 4.33 and 1.64 ind./km respectively (Figure 4). This suggests that crocodile observation by spotlight night count method is more effective by using traditional boats and on foot, compared to speedboats and longboats. This is likely due to the influence of machines used to affect crocodile activity. The sound of the machine will give the effect of crocodile discomfort on its habitat.

According to Richard et al. (2002), the crocodile population in the Mamberamo Foja area is very high. In fact, in addition to freshwater crocodiles $(C$. novaeguineae), some large reptiles such as giant labi-labi (Pelochelys cantori), and Irian turtles (Elseya novaeguineae) are also found in this area. These three types of fauna are known to be widely used by the community, and some are a source of food for local people. The implementation of freshwater crocodile population monitoring survey conducted by BBKSDA Papua Province, often faces various problems in the field. Similarly, when the survey team for this study. The rainy season is very disruptive to the observation process in the field, so the results are not maximized. The problem concerns the size of the area, the number of survey personnel, the costs needed, and most of the locations of the area are difficult to reach. Freshwater crocodile monitoring surveys have been started in 1987, and are still ongoing today.

\section{Habitat of Crocodylus novaeguineae}

The results showed that crocodiles are often found in freshwater water system areas. The condition of the area that has the majority of lowland swamp types becomes a suitable habitat for crocodile development. Lowland forest vegetation also supports the presence of crocodiles. Most crocodiles are found around the water system of rivers along the Mamberamo River. The water system of small and large rivers, swamps, ponds, and lakes becomes a comfortable habitat for freshwater crocodiles.

Good forest conditions support the development habitat of freshwater crocodiles in WRMF. Most of the swamp forest area in this lowland area is sago plantation forest, especially in upstream, and downstream areas. Some are hilly in the middle. Along with the Mamberamo River water system and river branches, it is known to grow various types of shrubs. Saccharum spontaneum and Phragmites and other grasses. According to Kurniati et al. (2017), crocodiles are often found in aquatic systems. The dominant plants in Crocodylus siamensis crocodile habitat found on the Mahakam River are Hanguana malayana, Phragmites karka, and floating grass. Furthermore, it is revealed that like most crocodiles, $C$. novaeguineae inhabits a variety of grassy and wooded swamps in lowland freshwater areas.

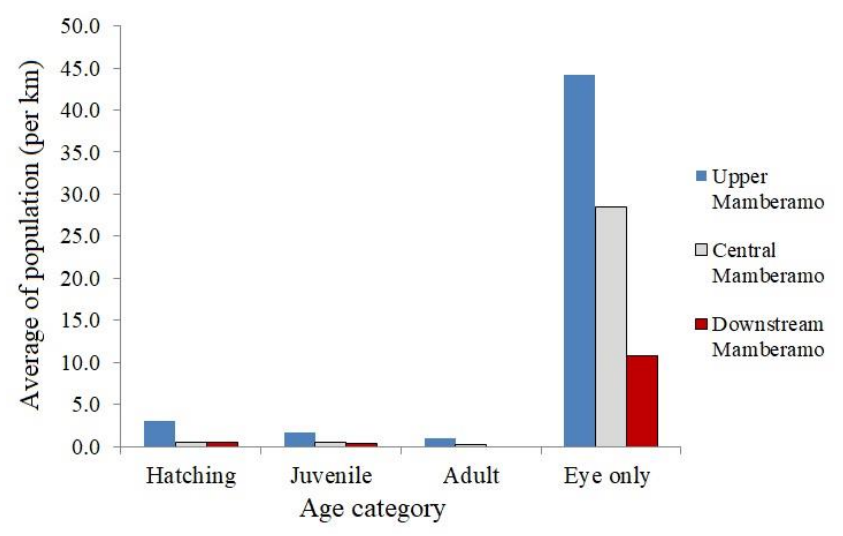

Figure 3. The average number of Crocodylus novaeguineae populations by age found in the Wildlife Reserve of Mamberamo Foja area, Papua, Indonesia

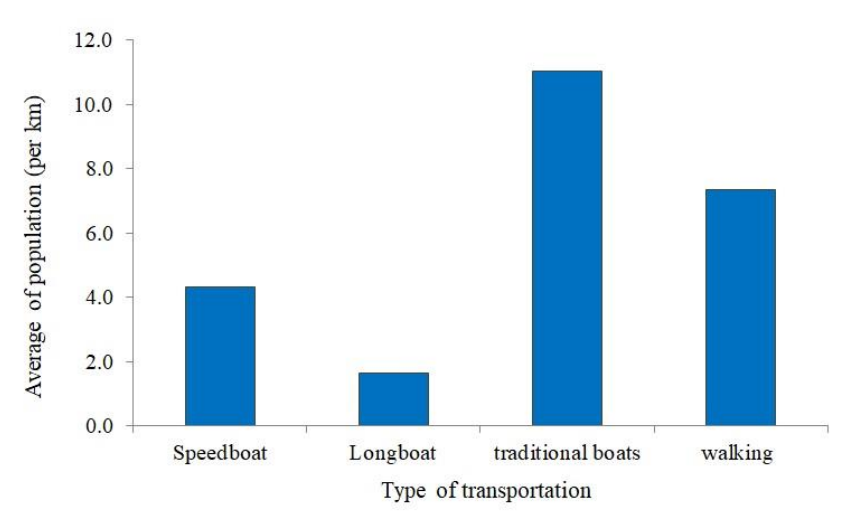

Figure 4. The estimated number of Crocodylus novaeguineae populations is based on means/means of transportation for observation 
Table 2. Freshwater Crocodylus novaeguineae population data based on hatchling, juvenile, adult age category, and only visible light in the eyes at WRMF, Papua, Indonesia

\begin{tabular}{|c|c|c|c|c|c|c|c|}
\hline \multirow{2}{*}{ Area of survey } & \multirow{2}{*}{$\begin{array}{c}\text { Times } \\
\text { (years) }\end{array}$} & \multicolumn{4}{|c|}{ Age category } & \multirow{2}{*}{$\begin{array}{c}\text { No. } \\
\text { of } \\
\text { inds. }\end{array}$} & \multirow{2}{*}{$\begin{array}{l}\text { Dens. } \\
\text { (ind./ } \\
\text { km) }\end{array}$} \\
\hline & & $\mathbf{H}$ & $\mathbf{J}$ & $\mathbf{A}$ & EO & & \\
\hline \multicolumn{8}{|c|}{ Upper Mamberamo (Pagai-Dabra) } \\
\hline \multirow[t]{4}{*}{ River of Mamberamo Mati } & 2002 & 1 & 1 & 0 & 53 & 55 & 2.5 \\
\hline & 2003 & 17 & 0 & 0 & 73 & 90 & 7.5 \\
\hline & 2008 & 3 & 0 & 0 & 19 & 22 & 8.8 \\
\hline & 2012 & 0 & 1 & 0 & 15 & 16 & 3.3 \\
\hline \multirow[t]{3}{*}{ River of Mamb. Mati I } & 2015 & 0 & 0 & 0 & 18 & 18 & 3.5 \\
\hline & 2016 & 0 & 0 & 0 & 24 & 24 & 3.9 \\
\hline & 2017 & 0 & 0 & 0 & 18 & 18 & 1.0 \\
\hline \multirow[t]{3}{*}{ River of Mamb. Mati I } & 2015 & 0 & 0 & 0 & 36 & 36 & 2.1 \\
\hline & 2016 & 0 & 0 & 0 & 5 & 5 & 0.3 \\
\hline & 2017 & 0 & 0 & 0 & 10 & 10 & 0.6 \\
\hline \multirow[t]{4}{*}{ River of Diaro } & 2012 & 1 & 0 & 0 & 25 & 26 & 4.3 \\
\hline & 2015 & 0 & 0 & 0 & 22 & 22 & 3.5 \\
\hline & 2016 & 0 & 0 & 0 & 18 & 18 & 2.4 \\
\hline & 2017 & 0 & 0 & 0 & 12 & 12 & 1.9 \\
\hline \multirow[t]{4}{*}{ River of Baso } & 2012 & 0 & 1 & 0 & 9 & 10 & 3.2 \\
\hline & 2015 & 0 & 0 & 0 & 5 & 5 & 1.1 \\
\hline & 2016 & 0 & 0 & 0 & 4 & 4 & 1.3 \\
\hline & 2017 & 0 & 0 & 0 & 8 & 8 & 1.4 \\
\hline \multirow[t]{4}{*}{ Kamika Pond } & 2001 & 0 & 47 & 41 & 316 & 404 & 13.5 \\
\hline & 2002 & 4 & 20 & 6 & 287 & 317 & 12.7 \\
\hline & 2003 & 55 & 0 & 0 & 167 & 222 & 18.5 \\
\hline & 2008 & 16 & 11 & 0 & 56 & 83 & 16.6 \\
\hline \multirow[t]{4}{*}{ Waropen Pond } & 2002 & 0 & 3 & 0 & 32 & 35 & 14.0 \\
\hline & 2003 & 9 & 1 & 0 & 49 & 59 & 19.7 \\
\hline & 2008 & 5 & 1 & 0 & 38 & 44 & 17.6 \\
\hline & 2012 & 0 & 0 & 0 & 2 & 2 & 1.3 \\
\hline \multirow{4}{*}{ Kweri Satu Pond } & 2002 & 1 & 2 & 0 & 47 & 50 & 12.5 \\
\hline & 2003 & 7 & 0 & 2 & 43 & 52 & 10.4 \\
\hline & 2008 & 3 & 2 & 0 & 36 & 41 & 13.7 \\
\hline & 2012 & 0 & 1 & 0 & 2 & 3 & 1.67 \\
\hline Kweri Dua Pond & 2002 & 1 & 4 & 0 & 45 & 50 & 10.0 \\
\hline & 2003 & 7 & 0 & 2 & 43 & 52 & 10.4 \\
\hline & 2008 & 10 & 1 & 0 & 19 & 30 & 10.0 \\
\hline & 2012 & 0 & 1 & 0 & 0 & 1 & 0.7 \\
\hline Apuse Pond & 2002 & 0 & 3 & 0 & 23 & 26 & 8.7 \\
\hline & 2003 & 7 & 0 & 0 & 38 & 45 & 11.3 \\
\hline & 2008 & 4 & 1 & 0 & 20 & 25 & 10.0 \\
\hline & 2012 & 0 & 0 & 0 & 2 & 2 & 3.3 \\
\hline Bernekam Satu Pond & 2008 & 8 & 0 & 0 & 19 & 27 & 10.8 \\
\hline & 2012 & 0 & 0 & 0 & 2 & 2 & 2.9 \\
\hline & 2015 & 0 & 0 & 0 & 10 & 10 & 1.8 \\
\hline & 2016 & 1 & 0 & 0 & 11 & 12 & 1.2 \\
\hline Bernekam Dua Pond & 2008 & 4 & 0 & 0 & 30 & 34 & 13.6 \\
\hline & 2012 & 0 & 0 & 0 & 9 & 9 & 2.0 \\
\hline & 2015 & 0 & 0 & 0 & 31 & 31 & 13.8 \\
\hline & 2016 & 0 & 0 & 1 & 5 & 6 & 2.1 \\
\hline Cabang Tiga Satu Pond & 2008 & 3 & 0 & 0 & 21 & 24 & 9.6 \\
\hline & 2012 & 0 & 0 & 1 & 19 & 20 & 5.4 \\
\hline & 2015 & 0 & 0 & 0 & 22 & 22 & 3.5 \\
\hline & 2017 & 0 & 0 & 0 & 5 & 5 & 1.9 \\
\hline Cabang Tiga Dua Pond & 2012 & 0 & 1 & 0 & 24 & 25 & 6.3 \\
\hline & 2015 & 0 & 0 & 0 & 74 & 74 & 10.3 \\
\hline & 2016 & 4 & 0 & 0 & 0 & 4 & 3.3 \\
\hline & 2017 & 0 & 0 & 0 & 24 & 24 & 1.5 \\
\hline Tanjung Putus Pond & 2015 & 0 & 0 & 0 & 2 & 2 & 2.2 \\
\hline & 2017 & 0 & 0 & 0 & 2 & 2 & 0.6 \\
\hline Sungai Besar & 2015 & 0 & 0 & 0 & 278 & 278 & 2.0 \\
\hline & 2016 & 9 & 0 & 2 & 166 & 177 & 1.4 \\
\hline & 2017 & 0 & 0 & 0 & 217 & 217 & 1.7 \\
\hline & Averas & & & & & & 6.22 \\
\hline
\end{tabular}

Central Mamberamo (Dabra - Foi)

$\begin{array}{llllllll}\text { River of Tayefe } & 2014 & 0 & 0 & 0 & 12 & 12 & 0.8\end{array}$

$\begin{array}{lllllll}2015 & 0 & 0 & 0 & 9 & 9 & 0.6\end{array}$

$\begin{array}{lllllll}2014 & 0 & 0 & 0 & 7 & 7 & 1.4 \\ 2015 & 0 & 1 & 0 & 11 & 12 & 1.2\end{array}$

$\begin{array}{lllllll}2016 & 0 & 0 & 0 & 2 & 2 & 0.3\end{array}$

$\begin{array}{lllllll}2017 & 0 & 0 & 0 & 4 & 4 & 0.4\end{array}$

$\begin{array}{llllllll}\text { Ajah Pond } & 2014 & 1 & 0 & 0 & 14 & 15 & 1.5\end{array}$

$\begin{array}{lllllll}2015 & 0 & 0 & 0 & 4 & 4 & 0.9\end{array}$

$\begin{array}{lllllll}2017 & 0 & 0 & 0 & 2 & 2 & 0.3\end{array}$

$\begin{array}{llllllll}\text { River of Pakuja } & 2015 & 0 & 0 & 0 & 24 & 24 & 3.8\end{array}$

$\begin{array}{lllllll}2017 & 0 & 0 & 0 & 19 & 19 & 3.2\end{array}$

$\begin{array}{llllllll}\text { River of Soi } & 2002 & 0 & 0 & 0 & 39 & 39 & 3.3\end{array}$

$\begin{array}{lllllll}2014 & 0 & 0 & 0 & 14 & 14 & 2.2\end{array}$

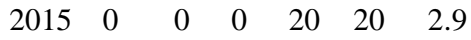

$\begin{array}{lllllll}2016 & 0 & 0 & 0 & 4 & 4 & 0.6\end{array}$

$\begin{array}{llllllll}\text { Sobaki Pond } & 2014 & 0 & 0 & 0 & 17 & 17 & 2.4\end{array}$

$\begin{array}{lllllll}2015 & 0 & 0 & 0 & 6 & 6 & 0.9\end{array}$

$\begin{array}{lllllll}2016 & 1 & 0 & 0 & 10 & 11 & 1.3\end{array}$

$\begin{array}{lllllll}2017 & 0 & 0 & 0 & 21 & 21 & 2.1\end{array}$

$\begin{array}{llllllll}\text { Korwate Pond } & 2015 & 0 & 12 & 8 & 70 & 90 & 8.6\end{array}$

$\begin{array}{lllllll}2016 & 6 & 0 & 0 & 65 & 71 & 4.6\end{array}$

$\begin{array}{lllllll}2017 & 0 & 0 & 0 & 17 & 17 & 2.6\end{array}$

River of Haya/Hoi $\quad 2014 \quad 00000018$

$\begin{array}{lllllll}2015 & 0 & 0 & 0 & 18 & 18 & 4.7\end{array}$

$\begin{array}{lllllll}2016 & 0 & 0 & 0 & 12 & 12 & 3.0\end{array}$

$\begin{array}{lllllll}2017 & 0 & 0 & 0 & 13 & 13 & 2.8\end{array}$

$\begin{array}{llllllll}\text { River of Mamb.-Rouffaer } & 2015 & 0 & 0 & 0 & 218 & 218 & 1.9\end{array}$

$\begin{array}{lllllll}2016 & 0 & 2 & 0 & 84 & 86 & 0.6\end{array}$

$\begin{array}{lllllll}2017 & 8 & 0 & 0 & 73 & 81 & 0.4\end{array}$

Average $\quad \mathbf{2 . 2 1}$

\section{Downstream Mamberamo}

Kwala Pond

$\begin{array}{lllllll}2014 & 0 & 0 & 0 & 9 & 9 & 3.8\end{array}$

River of Disimbo

$\begin{array}{lllllll}2015 & 1 & 2 & 0 & 10 & 13 & 5.4\end{array}$

$\begin{array}{lllllll}2014 & 0 & 0 & 0 & 6 & 6 & 1.1\end{array}$

$\begin{array}{lllllll}2015 & 2 & 2 & 0 & 7 & 11 & 2.0\end{array}$

River of Nanesi

$\begin{array}{lllllll}2014 & 0 & 0 & 0 & 5 & 5 & 0.6\end{array}$

$\begin{array}{lllllll}2015 & 0 & 0 & 0 & 5 & 5 & 0.6\end{array}$

$\begin{array}{llllllll}\text { River of Ibhai } & 2014 & 0 & 0 & 0 & 5 & 5 & 0.8\end{array}$

$\begin{array}{llllllll} & 2015 & 0 & 0 & 0 & 4 & 4 & 0.6\end{array}$

$\begin{array}{llllllll}\text { Warmarisya Pond } & 2014 & 3 & 0 & 0 & 29 & 32 & 8.7\end{array}$

$\begin{array}{llllllll}\text { River of Yarui } & 2014 & 0 & 0 & 0 & 11 & 11 & 0.9\end{array}$

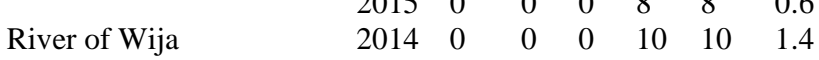

$\begin{array}{lllllll}2015 & 2 & 1 & 0 & 11 & 14 & 1.9\end{array}$

$\begin{array}{llllllll}\text { River of Mamb. Besar } & 2014 & 0 & 0 & 0 & 20 & 20 & 1.2\end{array}$

$\begin{array}{lllllll}2015 & 0 & 0 & 0 & 21 & 21 & 1.2\end{array}$

$\begin{array}{lll}\text { Average } & \mathbf{2 . 0 5}\end{array}$

Notes: Calculation of the number of individuals based on crossdistance surveys; H: hatchling (infant), J: juvenile, A: adult; EO: eye only

In general, the presence of crocodiles in their habitat depends on the natural conditions of an area. Some crocodile nesting sites have diverse habitats in the Northern Territory of Australia. Crocodiles are found in closed high grasslands, waterlogged plains with dominant plant species Oryza, open forest with dominant plant species Melaleuca, closed forests with dominant plant species Eucalyptus, Melaleuca, and Pandanus, salt-tolerant grasslands mangrove fringes, and open forest area Eucalyptus miniata (Fukuda and Cuff 2013). This condition also affects the density of hatchlings found especially related to the rainy season (Fukuda and Saalfeld 2014). 


\section{Diversity of tree vegetation species}

The observations showed that there were about 112 types of tree-level vegetation in the WRMF area in Papua (Table 3). Based on the appearance of topography, the area of WRMF is divided into two important parts, namely the marshy forest area and the hill-mountain area in the central part. This condition affects the composition of vegetation in the WRMF area. The marshy forest area in the northern part of WRMF (north coast, around Lake Rombebai, to Kasonaweja) is dominated by mangrove forests in coastal areas (Mamberamo Raya and Sarmi Districts), swamp forests with dominant vegetation sago (Metroxylon sago), and lowland forests dominated by ironwood (Intsia palembanica and I. bijuga) and matoa (Pometia pinnata). In the secondary forest area 7 types of Ficus plants were found, with some types of plants typical of secondary forests such as Macaranga, Glochidion, and Nauclea.

Based on 112 species of tree vegetation found, most of the diversity levels are found in the central area of WRMF, especially in Kwerba with the number of types 56, followed by the forest area Dabra (Upper Mamberamo) 52 species, forest area of Suaseso Village (Mamberamo downstream) 49 species, Pagai forest (upper) 44 species, while in the lake area only found about 16 types of plant groups of trees (diameter more than $10 \mathrm{~cm}$ ) (Table 3; Figure 6). In the lake area and its surroundings, the habitat of growing trees is dominated by swamps. This causes the type of plants that are able to grow and develop less. According to de Fretes et al. (2002) in Dabra Sub-district at least 121 species of tree group plants were found, especially in the Furu river area and 90 species in the Tiri river. Both areas are dominated by Vatica rassak, Hopea sp., P. pinnata, I. bijuga, I. palembanica, and Garcinia sp.

In the area of WRMF in the central part (Kwerba and its surroundings) with the topography of hills to mountains dominated by vegetation species of tree plants, while sago plants do not dominate. In this area are found species of plants Ficus, Intsia, Syzygium, and Pometia. In the southern area of WRMF (Airu Sub-district, Jayapura) the dominant vegetation found among others is I. bijuga, Michelia sp., $P$. pinnata, Nauclea papuana, and Palaquium spp. In Dabra sub-district is known to be dominated by Gymnacranthera farqihariana, Cinammomum cullilawan, Lithocarpus rufovillosus, Sterculia macrophylla, P. pinnata, and Intsia sp. According to Suharno and Tanjung (2011), the lowland area of Papua is dominated by specific plants such as matoa (P. pinnata) and merbau (I. bijuga).

In marshy forest and lake areas, the Korwate Pond area is known to have a lower diversity. Based on rapid assessment, 16 types of plants were found, and dominated by sbaki plants (local name), Dillenia alata, Decaspermum, Tabernaemontana aurantiaca, Neonauclea acuminata, Syzygium sp., Nauclea spp., Intsia spp., Garcinia spp., Macaranga spp., and Ficus spp. The number of such types is smaller than other areas in the WRMF area.

In general, the Mamberamo Foja area is known to have a high variety of species, albeit with a small number of families. The family with the dominant number of species in the region comes from the families Moraceae, Burseraceae, Myrtaceae, Rubiaceae, Lauraceae,
Dipterocarpaceae, and Euphorbiaceae. This information is supported by Kartikasari et al. (2012) which shows that the diversity of flora in Papua is quite high, but with a smaller number of families compared to other areas in Indonesia.

In the survey that has been conducted, it is indicated that in this area found another type of crocodile, namely $C$. porosus, although it can not be proven in detail because the crocodile samples found have not been caught. According to Hall (1989) that the C. novaeguineae and C. porosus species are two endemic crocodile species found in New Guinea, including Papua. C. porosus crocodile is an estuary crocodile that has a wide distribution and is mostly found in coastal lowland areas. According to Brackhane et al. (2018), the potential habitat for C. porosus in East Timor is limited to a narrow plain between the coast and the mountain ridges, and includes mangroves.

The existence of $C$. novaeguineae is found in the northern and southern parts of the Central Highlands, which stretch from east to west dividing the entire island into the north and south. However, the population of $C$. novaguineae is not yet known for certain throughout the region (Hall 1989; Murray et al. 2019). Areas with aquatic systems, including freshwater and brackish water in coastal areas, are suitable habitats for crocodile development, including C. porosus (Britton 2012); Brackhane et al. 2018).

\section{Crocodile conservation challenges in WRMF Area}

The main challenges in managing and controlling crocodile populations at WRMF are land cover changes, land conversion, and crocodile hunting. The results of the identification of land closures in this area show that most of the population lives within the WRMF area. Population development and community migration culture are still the main problems in land use for housing needs. Population growth also affects the conversion of land into farmland, and other infrastructure facilities. Regional development is growing rapidly, so the development of the region both central and local government programs must be in line and need to consider the concept of sustainable development. The level of hunting of local communities also affects the population of freshwater crocodiles $C$. novaeguineae.

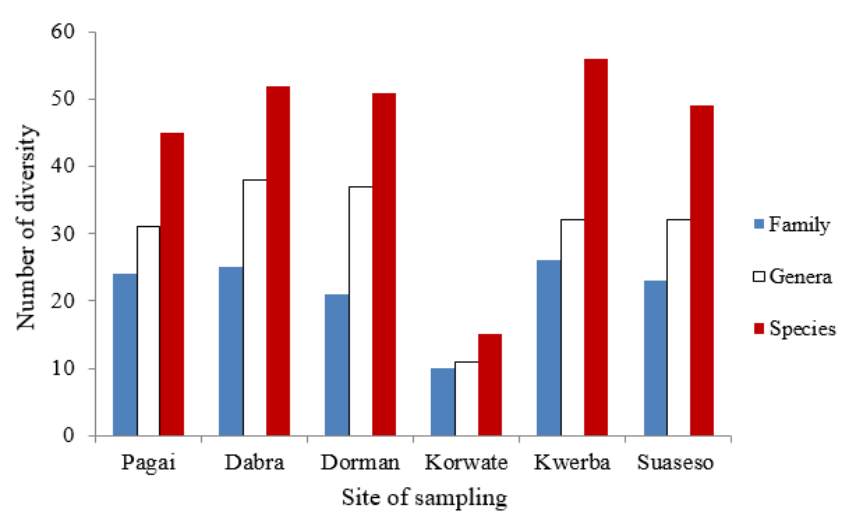

Figure 5. Tree group plant diversity in WRMF, Papua, Indonesia 
Table 3. Diversity of tree plants in the WRMF area, Papua, Indonesia

\begin{tabular}{|c|c|c|c|c|c|c|}
\hline \multirow[b]{2}{*}{ Types of plant } & \multicolumn{6}{|c|}{ Location/Villages } \\
\hline & 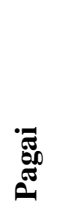 & 竎 & 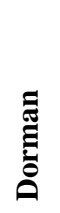 & 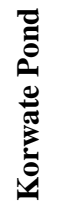 & $\overbrace{}^{\frac{0}{2}}$ & 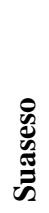 \\
\hline Aceratium sinuatum & & & & & + & + \\
\hline Actinodaphne nitida & & & & & & + \\
\hline Aglaia sp. & + & + & + & & & \\
\hline Alphitonia mollucana & & + & + & & + & \\
\hline Alstonia scholaris & + & & & & & \\
\hline Antiaris toxicara & + & + & + & & + & \\
\hline Antidesma baccatum & & + & & & & \\
\hline Artocarpus sp. & + & & + & & + & \\
\hline Baccaurea racemosa & & & + & & + & + \\
\hline Barringtonia sp. & + & & & & + & + \\
\hline Blumeodendron sp. & & + & + & & & \\
\hline Calophyllum euryphyllum & + & & & & + & \\
\hline Canarium decumanum & & + & + & & & \\
\hline Canarium indicum & & + & & & & + \\
\hline Canarium sp. & + & + & + & & + & + \\
\hline Canarium sp1. & + & & + & & & \\
\hline Canarium sp2. & + & + & & & & \\
\hline Chisocheton ceramiqus & & + & & & & \\
\hline Cinammoтum cullilawan & & + & + & & + & \\
\hline Cryptocaria sp. & + & & & & & \\
\hline Cynometra cauliflora & & + & + & & & + \\
\hline Decaspermum parviflorum & & & & + & & \\
\hline Dillenia alata & & & & + & & \\
\hline Dillenia sp. & & & & & + & + \\
\hline Dracontomellum edule & + & & & & & \\
\hline Dracontomelon sp. & & & & & + & + \\
\hline Dracontomelon dao & & & & & & + \\
\hline Elaeocarpus sphaericus & + & + & + & & + & \\
\hline Euphorbiaceae (sp) & & + & & & & \\
\hline Ficus microcarpa & + & + & & & + & \\
\hline Ficus macrophylla & & & + & & + & + \\
\hline Ficus melanocarpa & & + & + & & & \\
\hline Ficus simplicissima & & + & & & & \\
\hline Ficus variegate & & + & + & + & + & + \\
\hline Ficus treubii & + & & + & & + & + \\
\hline Ficus sp. & & & & & & + \\
\hline Ficus nodosa & & & + & & + & + \\
\hline Ficus villosa & + & & & & & \\
\hline Filebrunea sp. & + & & + & & + & \\
\hline Ganua boelageana & & + & + & & & \\
\hline Garcinia dulcis & + & + & & & + & \\
\hline Garcinia picrorhiza & & & & + & & \\
\hline Garcinia sp. & & & + & + & + & \\
\hline Geniostoma antherothricum & & & & & & + \\
\hline Geniostoma rupestre & + & + & + & & & \\
\hline Glochidion sp. & & & & & + & + \\
\hline Gnetum gnemon & & & + & & + & + \\
\hline Goniotallamus macropilus & & + & + & & & \\
\hline Gonocaryum litorale & & & & & & + \\
\hline Gynmacranthera farquhariana & & + & & & & + \\
\hline Hapolobus lanceolatus & & + & + & & & \\
\hline Hibiscus tiliaceus & + & & & & + & \\
\hline Homalium fogifolium & & + & + & & & \\
\hline Hopea iriana & & + & & & + & + \\
\hline Hopea papuana & & & + & & & + \\
\hline Horsfieldia sylvestris & + & + & + & & + & \\
\hline
\end{tabular}

Hydriastele $\mathrm{sp}$

Intsia acuminata

Intsia bijuga

Intsia palembanica

Leguminosae

Lithocarpus aspericupulus

Lithocarpus rufovillosus

Litsea firma

Litsea sp.

Litsea timoriana

Litsea tsinlingensis

Litsea tuberculata

Livistona papuana (palem kipas)

Lunasia amara

Macaranga gigantean

Macaranga sp.

Macaranga $\mathrm{sp} 2$ (buah parkit)

Macaranga sp3.

Macaranga triloba

Maniltoa psilogyne

Mastixiodendron pachyclados

Michelia sp.

Myristica fattua

Myristica sp.

Nauclea orientalis

Nauclea papuana

Neonauclea acuminata

Palaquium amboinensis

Palaquium sp.

Parastemon versteeghiii

Pisonia umbelliflora

Pohon Sego (local name)

Pohon Spagu (local name)

Polyalthia sp.

Polyaltia glauca

Pometia pinnata

Pometia sp.

Popowia macrocarpa

Sbaki (local name)

Semonrus grandifolius

Sloanea sp.

Sterculia macrophylla

Sterculia sp.

Syzygium papuana

Syzygium sp.

Syzygium sp4.

Syzygium $\mathrm{sp} 1$.

Syzygium $\mathrm{sp} 2$.

Syzygium sp3.

Tabernaemontana aurantiaca

Teijsmariodendron $\mathrm{sp}$.

Theobroma caco

Tijsmanniodendron hollrungii

Timonius sp.

Vatica papuana

Vatica rassak

Total

Notes: sampling area is $12.000 \mathrm{~m}^{2} ;+$ present
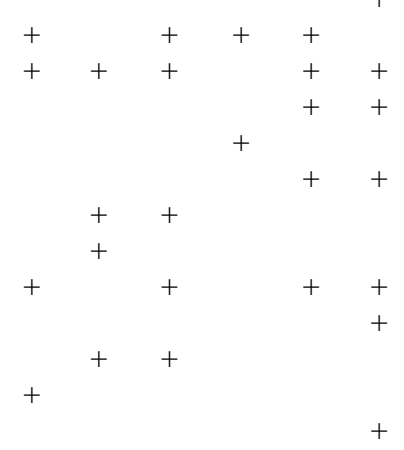

$+$
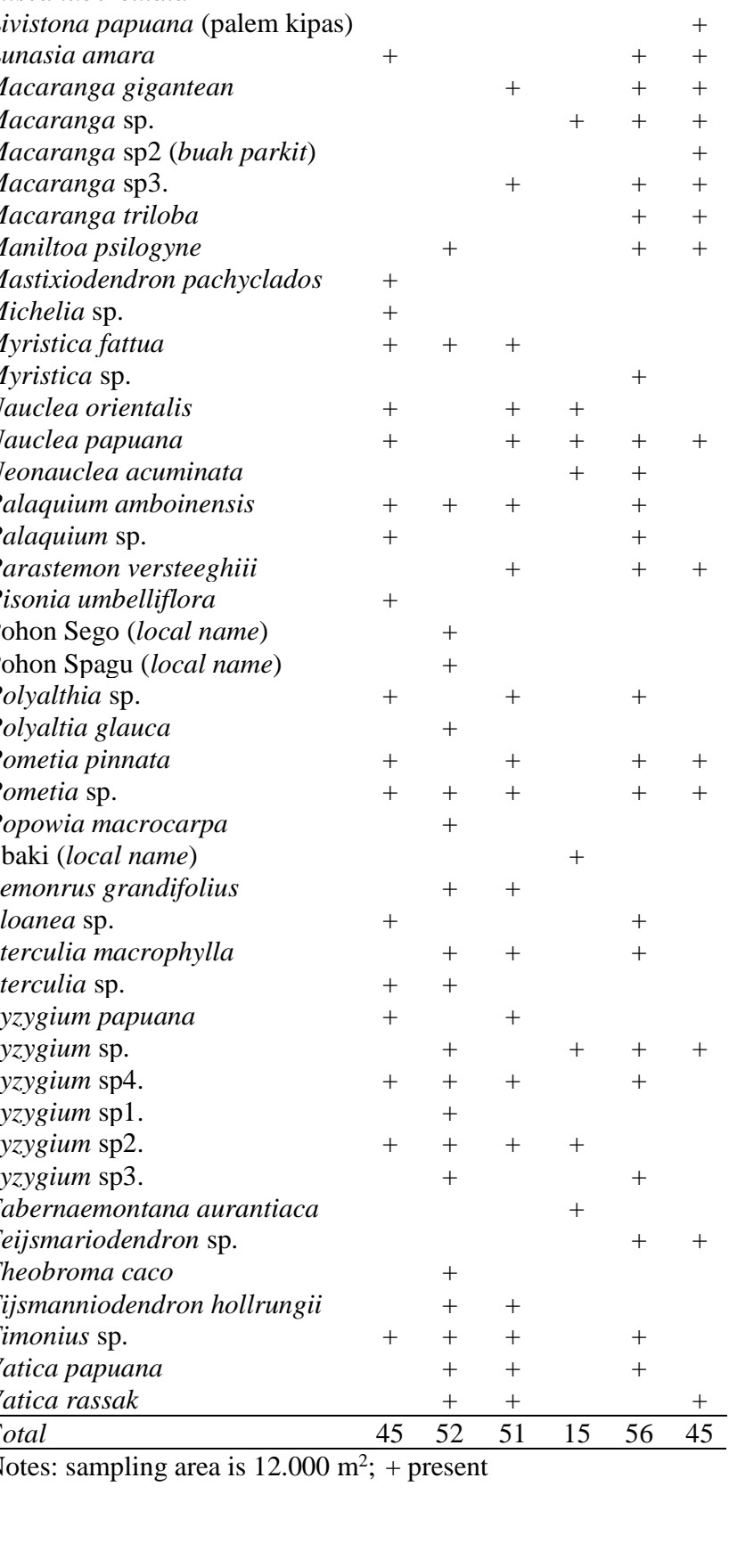

Crocodiles in the category of children are often hunted for enlargement purposes and sold, while large size crocodiles are taken skin and part of the meat for consumption. Based on interviews with the public, it is known that crocodile hunting in this area is still high. 
People hunt crocodiles for their skin and meat. Crocodile meat can be consumed by the community as a source of animal protein needs, while the skin is of high economic value. Some people make the hunt to increase the family's economic income. Crocodile skin is sold in inches. One inch ranges from Rp. 25.000,- to Rp. 35.000,-. According to Brauer (2003), Brackhane et al. (2018), and Handono et al. (2014) the socioeconomic condition of the community is one of the factors to evaluate conditions related to the conservation status of flora and fauna.

Until now the hunt is still ongoing even with varying intensity for each region. Based on the results of interviews with the community, hunting is carried out to meet economic needs, especially from the processing of crocodile skin. In these conditions, the economic needs of the people in this region rest on local natural resources. The northern area of Mamberamo bordering the beach is dominated by mangrove plants. Magnuson (1980), Read et al. (2004), and Murray et al. (2019), revealed that one of the comfortable crocodile habitats is the mangrove area.

According to Hall and Johnson (1987), the existence of C. novaeguineae had a major influence on the cultural and economic development of the local community. Therefore, According to Salem (2013), the great concern that needs to be protected is habitat and keeping crocodile populations stable which does not lead to the extinction process. Yule (2010) and Salem (2013) suggest that one of the potential loss of biological resources is habitats that affect ecosystems in an area. Related to this function, maintaining the integrity of the wildlife sanctuary becomes absolutely done. The business is not easy because WRMF has a large area that requires a lot of energy, cost, and time. Therefore, good cooperation between regional managers, governments, communities and stakeholders must be in line and sustainable.

\section{ACKNOWLEDGEMENTS}

We would like to express our gratitude to the head of BBKSDA Papua for granting permission for this study. We also appreciate the facilities and staff provided by the Function Conformity Evaluation Team (EKF) Mamberamo Foja 2018/2019 and the Head of Intsia Foundation in Tanah Papua (INTSIA) during the field survey.

\section{REFERENCES}

Brackhane S, Xavier FME, Gusmao M, Fukuda Y. 2018. Habitat mapping of the saltwater crocodile (Crocodylus porosus) in Timor-Leste. Herpetol Rev 49 (3): 439-441.

Brauer I. 2003. Money as a indicator: to make use of economics evaluation for biodiversity conservation. Agric Ecosyst Environ 98: 483-491. DOI: 10.1016/S0167-8809(03)00107-5.

Britton A. 2012. Crocodylus novaeguineae (Schmidt, 1928). Crocodilian species list. (online). Accessed December 5, 2019 at http://crocodilian.com/cnhc/csp_cnov.htm

Cox JH. 2010. New Guinea freshwater crocodile Crocodylus novaeguineae. In: Manolis SC, Stevenson C. (eds.) Crocodiles. Status Survey and Conservation Action Plan. $3^{\text {rd }}$ ed. Crocodile Specialist Group, Darwin. de Fretes Y, Rachman IA, Wally E. 2002. Vegetation of the Dabra Area, Mamberamo River Basin, Papua, Indonesia. RAP Bulletin of Biological Assesment No. 25. Conservation International, Washington DC., USA.

Fukuda Y, Cuff N. 2013. Vegetation communities as nesting habitat for the saltwater crocodiles in the Northern Territory of Australia. Herpetol Conserv Biol 8 (3): 641-651.

Fukuda Y, Saalfeld K. 2014. Abundance of saltwater crocodile hatchlings is related to rainfall in the preceding wet season in Northern Australia. Herpetologica 70 (4): 439-448. DOI: 10.1655/HERPETOLOGICAD-13-00096R3.

Hall PM. 1989. Variation in geographic isolates of the New Guinea crocodile (Crocodylus novaeguineae Schmidt) compared with the similar, allopatric, Philippine crocodile (C. mindorensis Schmidt). Copeia 1: 71-80. DOI: 10.2307/1445607.

Hall PM, Johnson DR. 1987. Nesting biology of Crocodylus novaeguineae in Lake Murray District, Papua New Guinea. Herpetologica 43 (2): 249-258.

Handono N, Tanjung RHR, Zebua LI. 2014. Structure of vegetation and economic value of mangrove forest in Youtefa Bay, Jayapura City Regency, Papua. J Biologi Papua 6 (1): 1-11. [Indonesian]

Hergoualc'h K, Carmenta R, Atmaja S, Martius C, Murdiyarso D, Purnomo H. 2018. Managing peatlands in Indonesia: Challenges and opportunities for local and global communities. Center for International Forestry Research (CIFOR), Bogor, Indonesia.

Hermawan MTT, Faida LRW, Wianti KF, Marhaento H, Anindia A. 2014. Pengelolaan Kawasan Konservasi. Gadjah Mada University Pres,. Yogyakarta. [Indonesian]

Hunter Jr. ML. 1996. Fundamental of conservation biology. Blackwell Science. Cambridge.

Indonesia Forest and Climate Support (IFACS). 2014. Planning of landscape conservation of Mamberamo Raya Regency, Papua Province. USAID-Indonesia Forest and Climate Support (IFACS), Jakarta. [Indonesian]

Indrawan M, Primarck RB, Supriatna J. 2007. Conservation biology. Yayasan Obor Indonesia, Jakarta. [Indonesian]

Kadir A, Tanjung RHR, Suharno, Rumahorbo BT, Reza DA. 2020. Soil physicochemical and ethnobiological studies on the peat swamp forests of Southern Papua, Indonesia. Biodiversitas 21 (4): 17141722. DOI: 10.13057/biodiv/d210454.

Kartikasari SS, Marshall AJ, Beehler BM. 2012. Papua Ecology. Series of Indonesia ecology. Penerbit Yayasan Pustaka Obor \& Conservation International, Jakarta.

Kurniati H, Nugroho A, Wiradinata EM. 2017. Review of Crocodylus novaeguineae from Indonesia. https://www.researchgate.net/ publication/321745999_

Magnusson EW. 1980. Habitat required for nesting by Crocodylus porosus (Reptilia: Crocodilidae) in Northern Australia. Aust J Wildl Res 7 (1): 149-156. DOI: 10.1071/WR9800149.

Man Z, Yishu W, Peng Y, Xiaobing W. 2011. Crocodilian phylogeny inferred from twelve mitochondrial protein-coding genes, with new complete mitochondrial genomic sequences for Crocodylus acutus and Crocodylus novaeguineae. Mol Phylogenet Evol 60 (1): 62-67. DOI: 10.1016/j.ympev.2011.03.029.

Mauger LA, Velez E, Cherkiss MS, Brien ML, Boston M, Mazzotti FJ, Spotila JR. 2012. Population assessment of the American crocodile, Crocodylus acutus (Crocodilia: Crocodylidae) on the Pacific coast of Costa Rica. Rev Biol Trop 60 (4): 1889-1901. DOI: 10.15517/rbt.v60i4.2188.

Montague JJ. 1984. Morphometric analysis of Crocodylus novaeguineae from the Fly River drainage, Papua New Guinea. Aust Wildl Res 11: 395-414. DOI: 10.1071/WR9840395.

Murray CM, Russo P, Zorrilla A, McMahan CD. 2019. Divergent morphology among populations of the New Guinea Crocodile, Crocodylus novaeguineae (Schmidt, 1928): Diagnosis of an independent lineage and description of a new species. Copeia 107 (3): 517-523. DOI: 10.1643/CG-19-240.

Papua Regional Government. 2012. Kajian Lingkungan Hidup Strategis Raperdasi RTRW Provinsi Papua 2010-2030. Propinsi Papua, Jayapura. [Indonesian]

Read MA, Miller JD, Bell IP, Felton A. 2004. The distribution and abundance of the estuarine crocodile, Crocodylus porosus, in Queensland. Wildl Res 31: 527-534. DOI: 10.1071/wr02025.

Richard S, Iskandar DT, Tjaturadi B. 2002. Amphibians and reptiles of the Dabra areas, Papua, Indonesia. RAP Bulletin of Biological 
Assessment No. 25. Conservation International, Washington DC., USA.

Salem AHI. 2013. Habitat vulnerability for the Nile Crocodile (Crocodylus niloticus) in Nasser Lake (Egypt). Transylv Rev Syst Ecol Res 15 (1): 19-32. DOI: 10.2478/trser-2013-0003.

Solmu G, Manolis C. 2019. Crocodylus novaeguineae. The IUCN Red List of Threatened Species 2019: e.T46591A3010398. DOI: 10.2305/IUCN.UK.2019-2.RLTS.T46591A3010398.en.
Suharno, Tanjung RHR. 2011. Matoa (Pometia sp): Potency, domestification, and their agriculture. Pustaka Pelajar, Yogyakarta. [Indonesian]

Tanjung RHR, Suharno, Kalor JD. 2012. Vegetation analysis and potency of non-timber forest in forest area at Pagai, Airu Dstrict, Jayapura Regency, Papua. Jurnal Biologi Papua 4 (2): 54-62. [Indonesian]

Yule CM. 2010. Loss of biodiversity and ecosystem functioning in IndoMalayan peat swamp forests. Biodivers Conserv 19: 393-409. DOI: 10.1007/s10531-008-9510-5. 